\title{
13. VOLCANIC ROCKS AND VOLCANIC CONSTITUENTS IN SEDIMENTS, LEG 21, DEEP SEA DRILLING PROJECT ${ }^{1}$
}

\author{
Michael Churkin, Jr., U.S. Geological Survey, Menlo Park, California \\ and \\ Gordon H. Packham, Department of Geology and Geophysics, University of Sydney, Australia
}

\section{INTRODUCTION}

Leg 21 was the first leg of the project to drill a sequence of deep-sea cores along a line of section that crosses an active volcanic arc-trench system, continues across a series of marginal ocean basins and ridges, and then extends onto a continental margin platform. Not surprisingly, abundant volcanic rocks and sediments rich in volcanic components were penetrated; these include several lithologies not previously found in deep-sea drilling. This report briefly describes the volcanic constituents found in each hole, correlates them between the holes, and finally makes a preliminary interpretation of their source and significance in the volcanic and tectonic history of the region.

\section{SITE 203}

The sparsely cored sequence at Site 203 ranges from late Miocene or early Pliocene to Holocene, and contains significant quantities of volcanic products intermixed with biogenic ooze (Figure 1). The abundance of volcanic products in the uncored section is indicated by the high rate of sedimentation-about 8 to $12 \mathrm{~cm} / 1000$ years.

The volcanic material comprises a variety of volcanic glass types predominantly acid to acid-intermediate, but more basic glass is present at the top and bottom of the section. The colorless glass has refractive indexes ranging from 1.506 to 1.540 , indicating a wide range in composition from rhyolitic to andesitic (Figure 2). Rarer palebrown glass of andesitic composition has refractive indexes of 1.54 to 1.57 and green glass of basaltic composition from 1.580 to 1.596 . In addition to the volcanic glass, there are grains of augite and more commonly plagioclase (refractive index 1.570 to 1.582 ) suggesting a calcic bytownite if only a single composition is present.

The glass shows a variety of shapes and morphological details. In Core 203-5-1, 77-78 cm, the glass is colorless and of an acid intermediate composition on the basis of a refractive index of about 1.53 . The surfaces of the grains are mostly broken vesicle walls, and only very minor conchoidally fractured surfaces are present (Plate 1, Figure 7). A sample from Core $203-3-5,85-86 \mathrm{~cm}$ at the base of a thick tuff bed, shows a much greater variation of vesicle size and shape (Plate 1, Figures 1-4), including common pipe vesicles (Plate 1, Figure 2; cf. Heiken, 1972, fig. 8). In addition, generally equant grains are characterized by smooth and curved surfaces that are broken vesicle walls

\footnotetext{
${ }^{1}$ Publication authorized by the Director, U.S. Geological Survey.
}

(Plate 1, Figures 1 and 7) and more rarely by conspicuous conchoidally fractured surfaces (Plate 1, Figure 4). Most of the ashes in the section appear morphologically similar to those characteristic of magmatic eruptions of andesitic to rhyolitic composition (Heiken, 1972). The origin of the black sand-size material composed of basalt glass $(n=1.58)$ and fresh olivine at the top of Core 203-5 and a similar sample obtained at the bottom of the hole is unresolved in the site description. The glass in each sample is characterized by low vesicularity and conchoidal fracture surfaces (Plate 1, Figure 11). Sands with these characteristics could have been produced in two ways-phreatomagmatic eruption of hyaloclastic ash or pounding by the drill on a vesicular basalt flow or shallow intrusion. However, the preponderance of conchoidally fractured surfaces favor the latter, purely mechanical origin. The size range of the fresh unconsolidated basalt fragments and the grading of these fragments according to size along the core suggest settling of pulverized basalt in a drilling mud rather than a natural sedimentalogical process of sorting.

All the biogenic oozes contain some volcanic glass, but most of the ash observed is present as discrete beds ranging from thin bands to a bed over 6.9 meters thick in Core 3 . This thick bed is a silty sand at the base, and its lower part, which is about a meter thick, is graded.

\section{SITE 204}

Site 204 drilled on the Pacific plate east of the Tonga trench is rich in volcanic detritus (Figure 1). Its upper part, Unit 1 , is a condensed section of Cenozoic abyssal clay, rich in volcanic glass and containing thin layers of glass shard ash. Most of this glass is colorless, but some glass shards are pale brown or green. All of the colorless glass has a refractive index $(n)$ of $<1.57$ and $>1.52$ and therefore is intermediate or andesitic in composition. The colored glass generally has a higher refractive index and is in the basic part of the intermediate field or is basic in composition. Most of the shards are very angular and irregular in shape, but rectangular and polygonal grains, some with abraded edges, are present (Plate 1, Figures 10 and 12). Parallel sets of elongated vesicles, as in Site 203, characterize many of the colorless glass shards. The shards are poorly sorted according to size; are as much as $0.7 \mathrm{~mm}$ across, and many are $0.3 \mathrm{~mm}$. Crystal inclusions in the glass are rare, but individual crystals of plagioclase and augite, although much less abundant than glass, are common. X-ray data indicate that in Unit 1, plagioclase occurs in samples at 49 meters and above, whereas only K-feldspar is found from 86 meters to 102 meters. High percentages of montmorillonite 

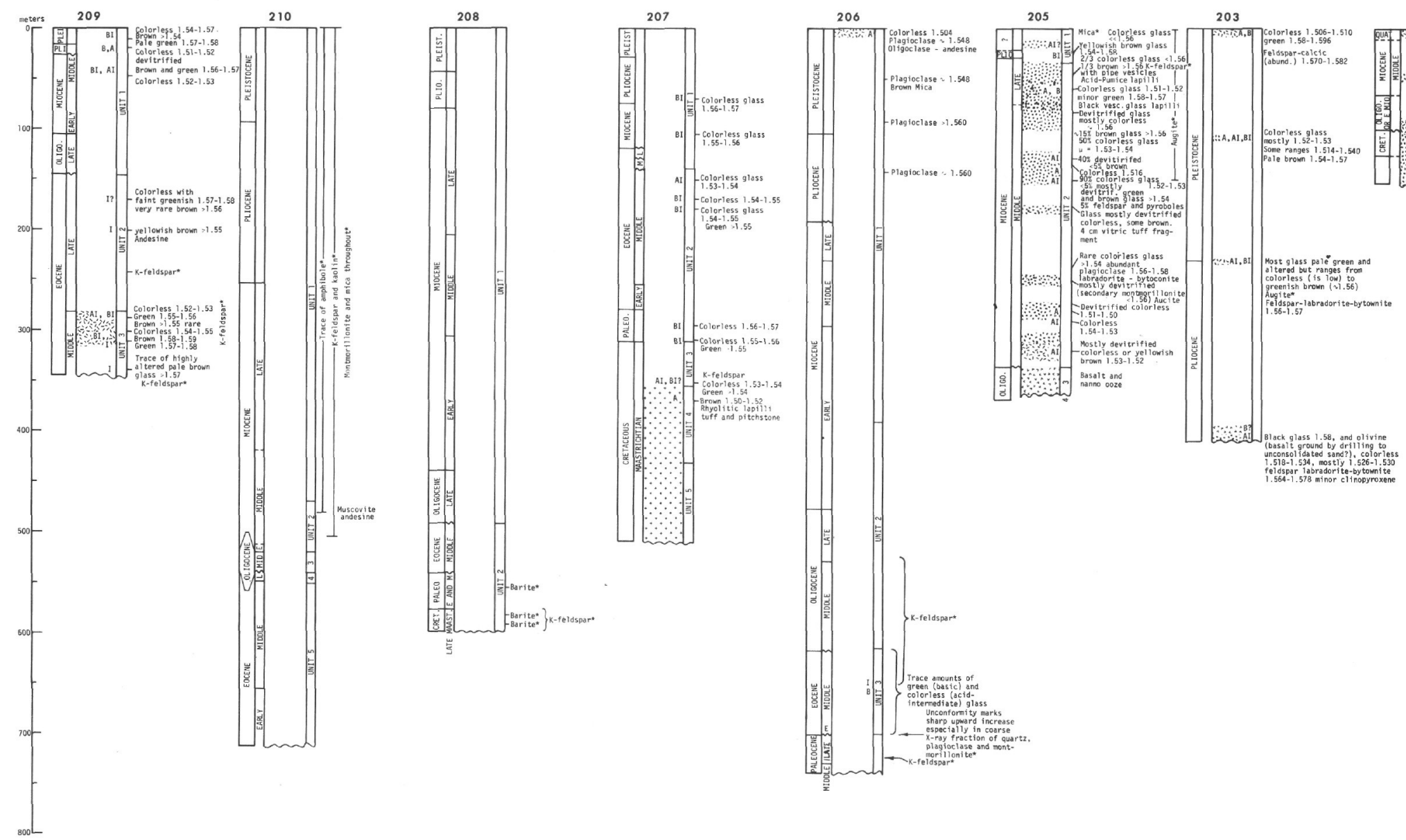

204

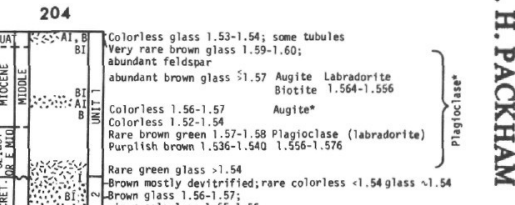

Figure 1. Columnar sections showing volcanic rocks and constituents at each drill site. 


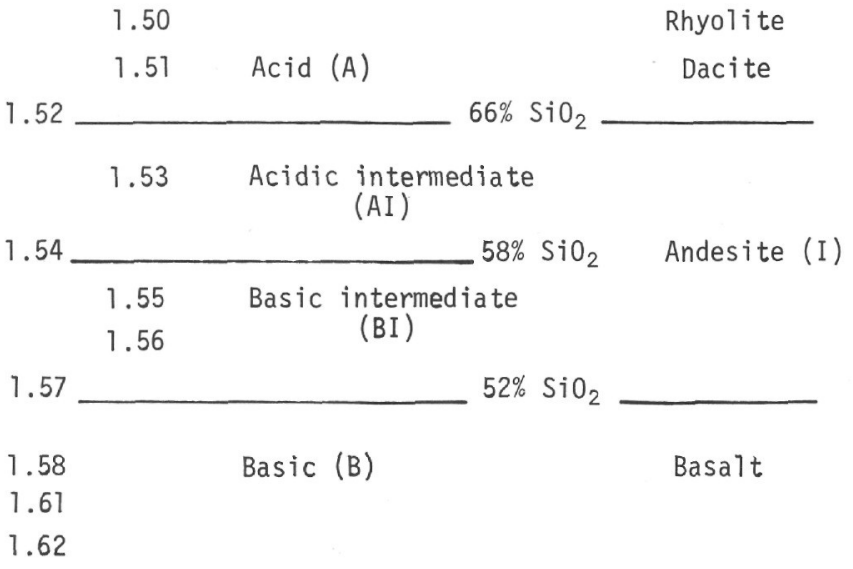

Figure 2. Refractive indexes (n) of volcanic glass, their $\mathrm{SiO}_{2}$ content, and classification. Adapted from george (1924) and Williams et al. (1955, fig. 9).

and zeolites indicate considerable alteration of volcanic constituents.

The lower part of the cored interval (102 to $147 \mathrm{~m}$ ) is composed of volcanogenic sediments and tuffs. From 103 to 126.5 meters (Unit 2), the volcanic detritus is abraded and has current structures indicating sedimentary transport (Figure 3, A, B). From 126.5 meters to the bottom of the hole at 147 meters (Unit 3), similar detritus is more angular and only vague stratification is present (Figure 3, C). The color and refractive index of the glass vary widely, reflecting mainly alteration but probably also some variations in volcanic source. These rocks are classified as vitric and lithic tuffs of intermediate composition. In the thin section, all of the detritus in Units 2 and 3 appears to be of volcanic origin and consists primarily of andesitic to basaltic rock fragments and intermediate glass, mainly brown but rarely colorless, with subordinate amounts of feldspar (andesine, where determined) and augite crystals.

In Unit 2 both the volcanic fragments and the finegrained tuffaceous matrix are highly altered. Much of the glass has devitrified, producing spherulitic structures and cracks filled with palagonite, zeolites, chloritic minerals, carbonate and minor epidote, and serpentine minerals. Considering the supposed pre-Eocene age of the rocks, the presence of some relatively clear glass is remarkable. Many of the glass fragments are highly irregular and may be corroded; also some radial fractures suggest that these fragments were hot when they came in contact with sea water.

In Core 204-9, the bottom of the hole, the glass shards are more altered than above; are various shades of brown, yellow, and pale green; and contain dark, dustlike impurities. These variously colored grains are somewhat birefringent and have refractive indexes ranging from 1.51 to 1.57. Less common colorless glass has refractive indexes of 1.52 to 1.55 . The matrix here is almost completely altered to fibrous serpentine and chlorite minerals.

\section{SITE 205}

The entire section drilled at Site 205 has abundant volcanic constituents. Glass-shard ash or vitric tuff forms most of the section and is interlayered with glass-shard- bearing or glass-shard-rich nanno ooze and clay (Figure 1).

Most of the glass particles have refractive indexes $<1.56$ (acid to acidic intermediate in composition) and are colorless. Subordinate amounts of pale-brown and green glass occur in the late Miocene and Pliocene parts of the section. These colored glasses have somewhat higher indexes of refraction (1.54-1.58) and range in composition from basic intermediate to basic; they can probably be related to volcanism on the nearby Lau Ridge that yielded the same range in composition (Figures 4 and 5). At 75 meters below the top of the section and lower, much of the glass is weakly birefringent owing to devitrification and foramtion of secondary minerals, especially montmorillonite. Some glass fragments in Core 205-23 have a fibrous structure (pumice) of tiny elongate vesicles (Plate 1, Figures 5, 6); others are flat glass plates and irregular fragments with one or more evenly curved sides (Plate 1, Figure 8). Morphological details of these glass shards, largely controlled by vesicles, resemble those from Sites 203 and 204 and are characteristic of magmatic eruptions of intermediate to acid composition. Most of the glass fragments are not appreciably abraded and probably were produced by explosive expansion of vesicle gases that disintegrated the rising magma colummn and produced air-fall ash. X-ray data show sizable amounts of augite in the intervals sampled at 155 meters and above in the hole. The feldspar is plagioclase except for K-feldspar found at 42 meters.

Broken crystals of feldspar. and pyrobole are another, although minor ( $<10 \%$ of the detritus), volcanic constituent in the vitric tuffs and tuffaceous sediments. The low level of crystallinity of the magma is also reflected in the scarcity of phenocrysts and microlites in glass fragments.

The basalt at the bottom of the hole has the following characteristics seen in thin section, where it comes in contact with nanno limestone (Figure 6).

1. Nanno limestone-Composed of recrystallized nannofossils. Of about 10 species of nanno plankton identified from semi-lithified nanno ooze several meters above the basalt-limestone contact, only Cycliargolithus floridanus, a species known elsewhere to be especially resistant to dissolution, was identified close to the contact (A. R. Edwards, personal communication, August 1973). In thin section, limestone is microbrecciated and cut by veinlets of calcite. A black opaque mineral, apparently the same as the iron and manganese oxide coating of the basalt, extends in a dendritic pattern $1 / 2 \mathrm{~mm}$ into the limestone.

2. Basalt-limestone sharp contact. Basalt-Outer rim is $1-1 / 2$ to $2-1 / 2-m m$-wide zone of deep-gold and dark-brown palagonite glass that contains scattered euhedral cyrstals of plagioclase and more rarely olivine. Banded and colloform structure is developed in the glass. Palagonite fills cracks that extend through the inner layer of unaltered glass and forms an irregular layer next to crystalline basalt that has a variolitic structure. Inner layer is a 3-4-mm-wide zone of fresh pale-brown glass (sideromelane) with isolated phenocrysts of plagioclase and olivine. Glass has dark spots especially around the edges of phenocrysts. These spots represent incipient variolitic structures. The glass has much less than 1 percent vesicles, and their small size $(<0.5 \mathrm{~mm})$ indicates emplacement at a depth $>1 \mathrm{~km}$ by analogy with 


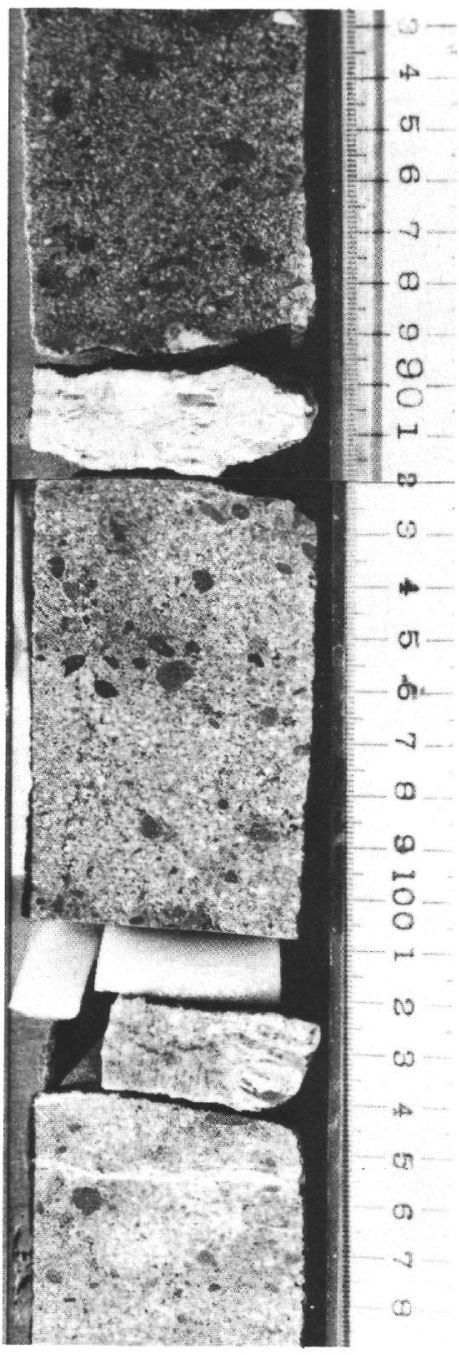

A

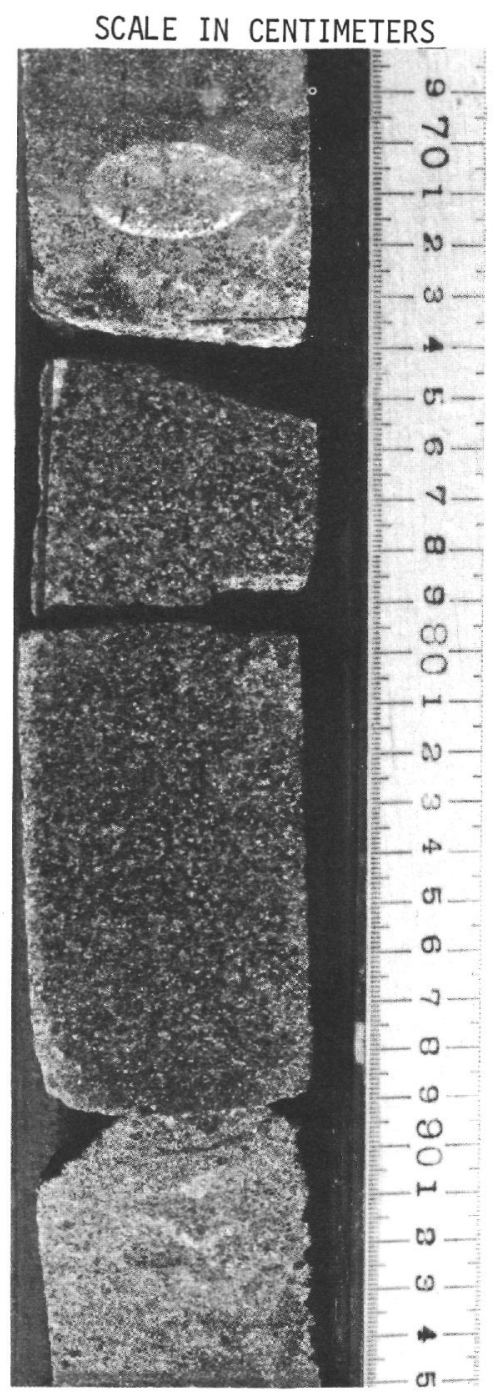

B
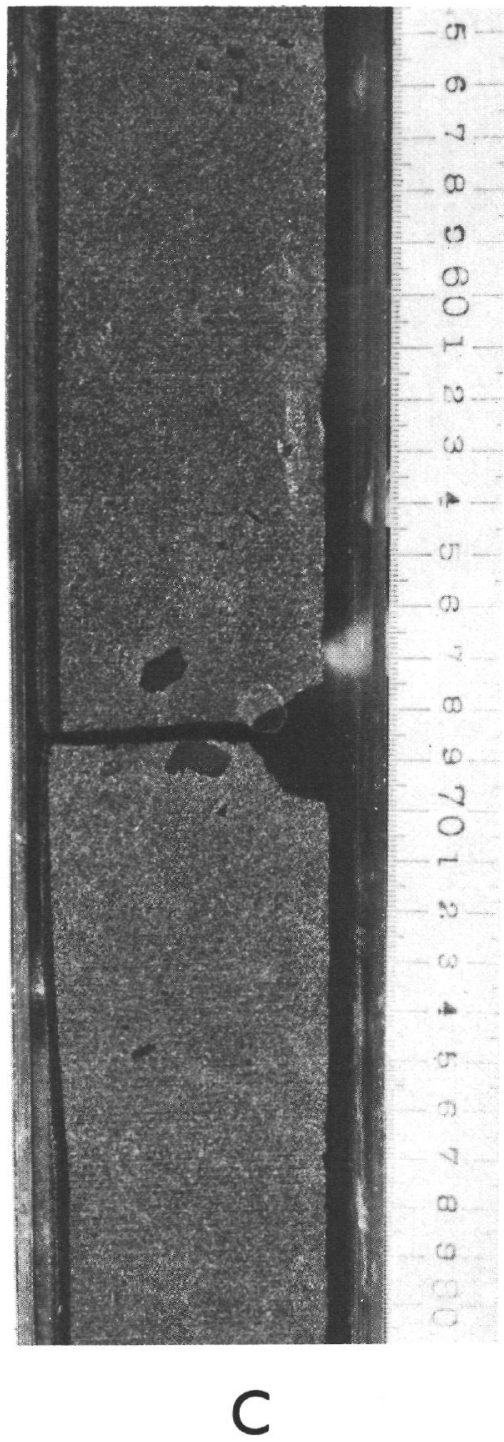

Figure 3. Textures of volcaniclastic rocks Site 204. (A) 204-1-6-1; (B) 204-2-7-2; (C) 204-3-9-2. Scale in centimeters.

studies of Hawaiian deep-sea basalts (Moore, 1965). Micron-size spherules in the rare vesicles closely resemble sulfide spherules characteristically found in modern submarine pillow lavas (Moore and Calk, 1971). About $1 \mathrm{~cm}$ inward from the outer edge of the glass layers is very finely crystalline basalt that has a variolitic structure of fibrous minerals. Scattered vesicles $1 \mathrm{~mm}$ to $0.1 \mathrm{~mm}$ in diameter form up to 15 percent of the crystalline basalt away from its contact with limestone.

Another type of contact between basalt and limestone is the sharp contact seen in Core 205-31-1, 2-6 cm, 28-32 cm, and $36-39 \mathrm{~cm}$ (left side of Figure 6). Here, finely crystalline and vesicular basalt lacking any apparent rim of glass but coated with 1 to $2 \mathrm{~mm}$ of black iron and manganese oxide is in direct contact with nanno limestone. Again dendritic structures of the black oxide mineral extend into the limestone, suggesting some secondary remobilization of the oxides.
At the bottom of the hole, which is 7 meters below its contact with limestone, the basalt has a diabasic texture composed of altered labradorite phenocrysts intergrown with clinopyroxene, probably augite. The groundmass is composed of highly altered glass, chloritic minerals, and some fibrous zeolite crystals. Vesicles $1 \mathrm{~mm}$ or less in diameter form about 20 percent of the rock.

The following features, when considered together, indicate that the basalt was a submarine flow (probably with pillow structures) that formed at great depth of water during sedimentation of nanno ooze:

1) Complicated and repetitious contacts of basalt and limestone in the core. Nanno ooze infilled the spaces between pillows and cracks.

2) Sequence of detailed textural changes from glass rim of basalt to variolitic basalt to vesicular crystalline basalt very closely resembling that in submarine pillow basalts (J. G. Moore, personal communication, January 1973). 


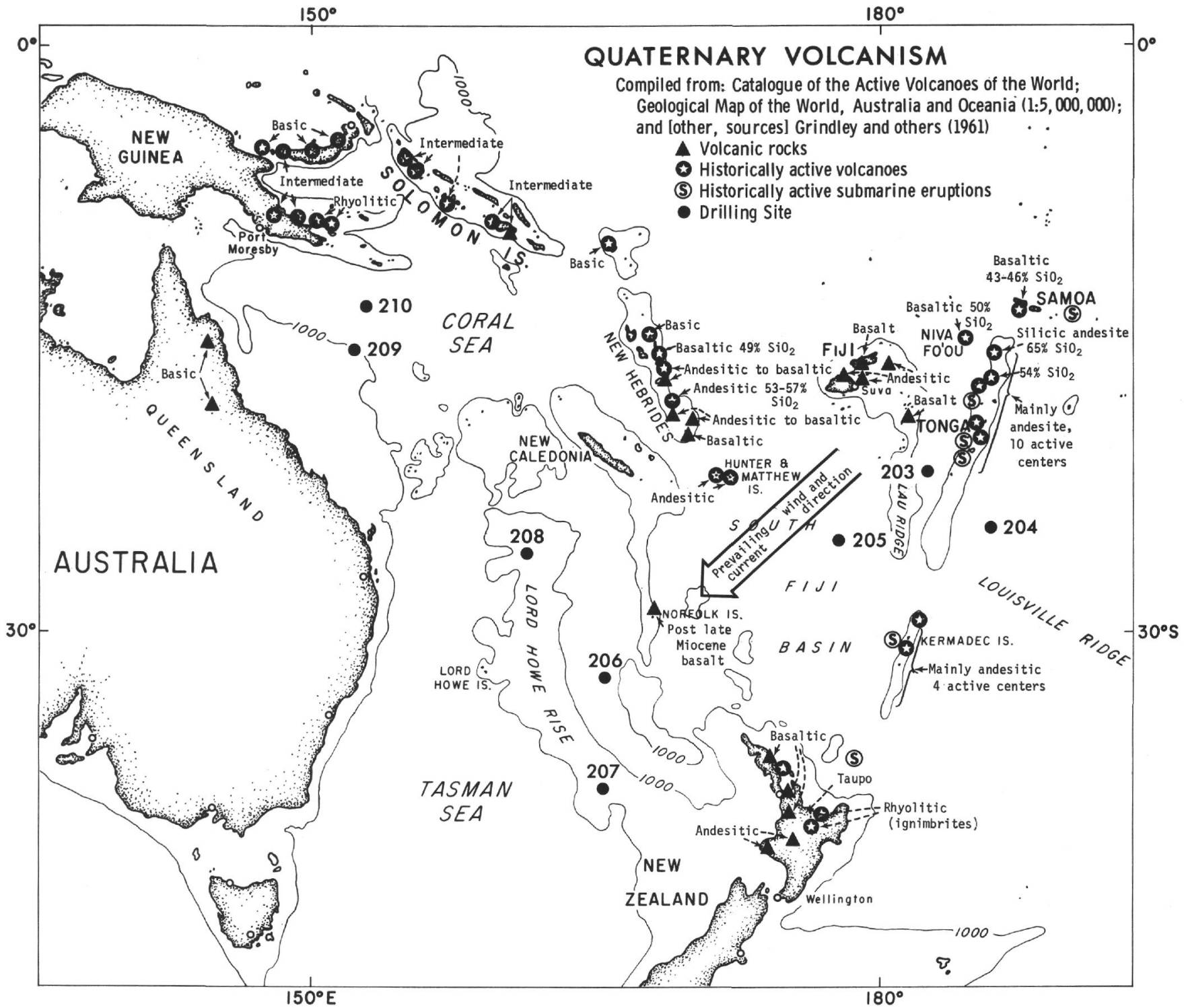

Figure 4. Quaternary volcanism of the southwest Pacific. Compiled from Catalogue of the Active Volcanoes of the World; geological map of the World, Australia and Oceanica (1:5,000,000); Fisher, 1957; grindley et al. (1961); and Richard (1962).

3) Manganese ${ }^{2}$-enriched iron ozide coating of both glass rim and crystalline basalt. Manganese-iron encrustation of this type is only known in submarine lavas that lie exposed on the sea floor for long periods of time. Furthermore, the rare elements and their percentages in the oxide coating closely resemble encrustations of submarine pillow lavas dredged from the slopes of the island of Hawaii (J.G. Moore, personal communication, January 1973).

The alternative explanation that was favored on shipboard is that the basalt intruded nanno ooze. This interpretation was based largely on the fact that limestone made of recrystallized nannofossils is in contact with the basalt. In this earlier interpretation, the induration of the limestone was attributed to baking of nanno ooze by basalt

\footnotetext{
${ }^{2} 10,000$ parts/million or about $1 \%$ in a semiquantitative spectrographic analysis. C. Heropoulos analyst.
}

intrusion. However, submarine lava in a sense can be considered intrusive where it flows into soft sediments. Also, the induration of the ooze adjacent to the lava may not be directly related to the emplacement of the basalt, but could result from preferential diagenesis of soft ooze in contact with the hard basalt. A laboratory experiment modeling various temperature and pressure conditions for recrystallization of the ooze could possibly verify the true nature of the contact.

\section{SITE 206}

Volcanic ash has been recognized in smear slides only at the top of the section (Plate 1, Figure 9). The ash is colorless and has a refractive index of 1.504 , indicating an acidic composition not unlike that at the top of Site 203. $\mathrm{X}$-ray data suggest some notable changes in siliceous detritus not detected in the visual core description. Above 


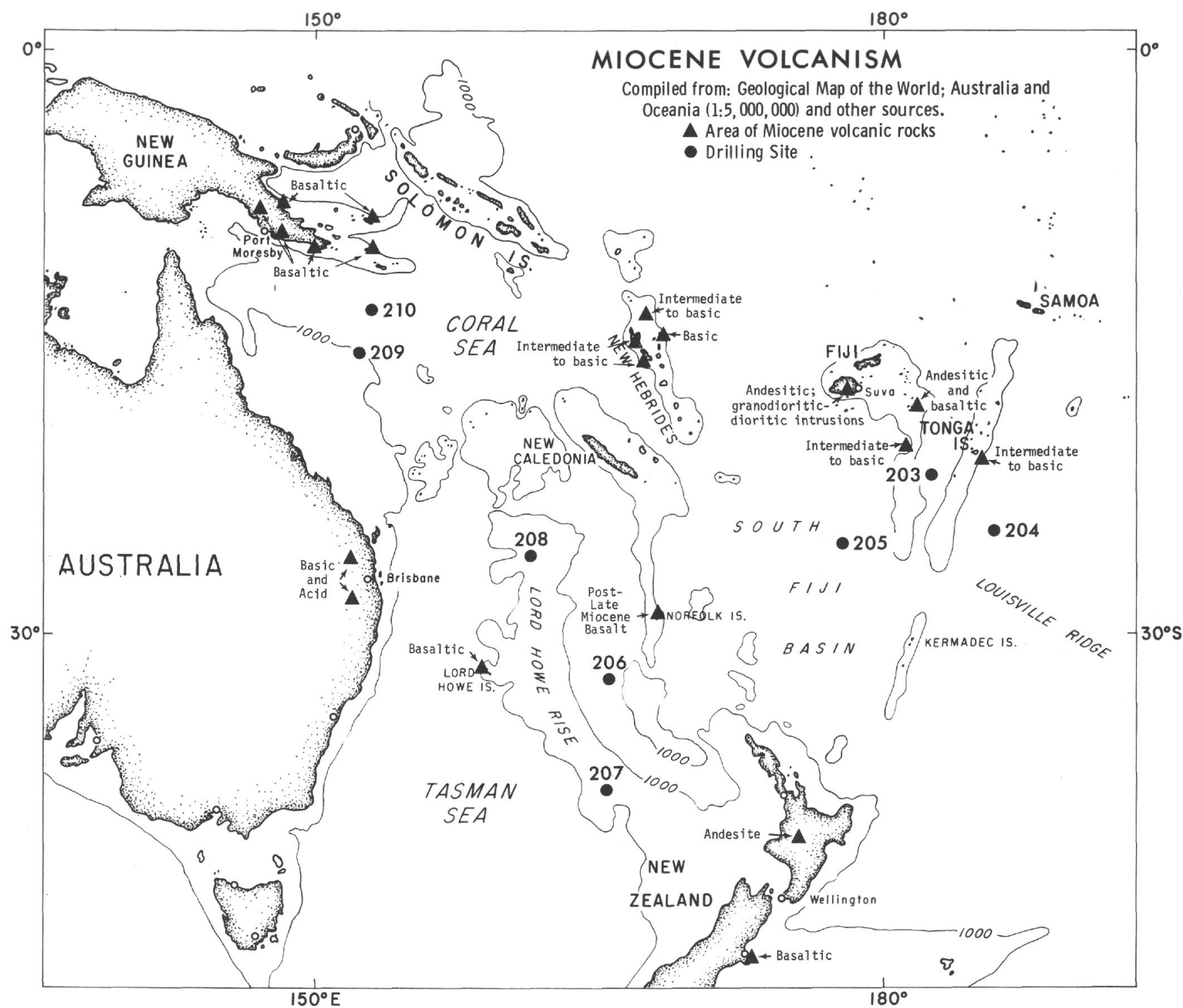

Figure 5. Miocene volcanism of the southwest Pacific. Compiled from Geological Map of the World; Australia and Oceanica (1:5,000,000); Fisher (1957); and Richard (1962).

the Paleocene-Eocene unconformity amounts of quartz, plagioclase, and montmorillonite increase sharply, especially in the coarse fraction. K-feldspar is present above the unconformity in the middle Eocene and middle Oligocene but also occurs in the Paleocene below the unconformity.

\section{SITE 207}

The upper two-thirds of the section drilled are composed of nearly pure calcareous ooze with only a trace of volcanic detritus totaling several percent at most (Figure 1). The detritus that is obviously volcanic consists of very rare glass shards.

The presence of trace amounts of zeolite, glauconite, and chlorite, together with substantial amounts of clay and chert, suggests that an originally higher percentage of volcanic material may have produced these secondary minerals.
The glass in the biogenic oozes is colorless or very pale green. The refractive indexes of the glasses ranging from 1.53 to 1.57 , indicate they are all intermediate in composition and are mostly basic intermediate.

In sharp contrast to the overlying calcaroues ooze, the lower part of the section is rhyolite (van der Lingen, this volume). Most of the rhyolite is composed of glass that is appreciably devitrified and argillized in the lowest part of the section. Phenocrysts of quartz, oligoclase-andesine, and, in the upper part of the section, sanidine, occur in the glass. The top of the rhyolite section is characterized by fragmental rocks-lapilli tuff and fragmented vitrophyric rhyolite, and the lower part of the section by more homogeneous vitrophyric rhyolite characterized by fluidal banding and perlitic and spherulitic textures. Plastically deformed lapilli, mainly elongated and collapsed pumice, that constitute the upper tuffaceous part of the rhyolite, have structures characteristic of welded tuffs. The mainly 

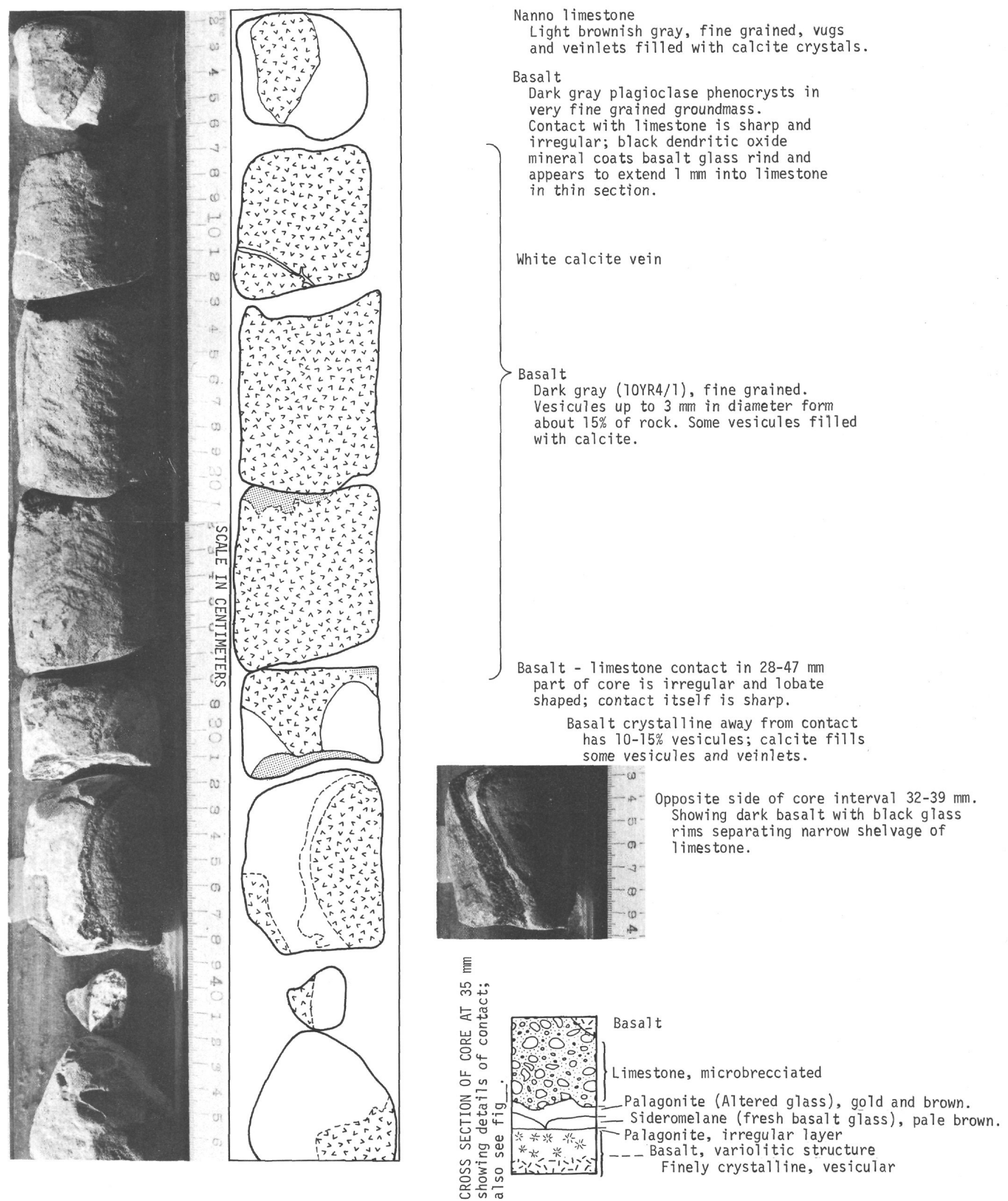

Figure 6. Contract relations between basalt and nanno limestone, Site 205-31-1. 
nonfragmental banded glass in the lower part of the section can be interpreted as the inner or lower part of an individual sheet of welded tuff of which the originally pyroclastic texture was annealed except in its outer margin (cf. with autobrecciated flow interpretations of van der Lingen, this volume).

The glasses that make up most of the rhyolite in the lower part of the hole have much lower refractive indexes ( $n=1.50-1.52)$ and these glasses do not appear to have contributed detritus to the overlying oozes. The silty claystone unit that directly overlies the rhyolite stratigraphically, however, has some reworked rhyolitic material at its base.

\section{SITES 208 AND 210}

Site 208 is remarkably free of volcanic constituents and does not contain a significant amount of terrigenous detritus. In 208 routine X-ray analyses were run only on the lowest part of the section of Late Cretaceous and Paleocene age. These analyses show parallels in composition with the lower parts of the sections at Sites 206 and 207, but in addition show substantial amounts of barite, the significance of which will be discussed later. Site 210 is also poor in volcanic material but has large quantities of terrigenous detritus that might easily obscure fine ash.

\section{SITE 209}

The section at Site 209 is composed mainly of biogenic sediments but, unlike the nearly pure carbonate ooze sections at Sites 208 and 207, has substantial amounts (10\%-50\%) of siliceous detritus, especially in the lower parts of the hole (Figure 1). Most of the detritus is silt or sand size and consists of quartz and feldspar characterized by microscopic impurities. These grains show signs of abrasion and alteration, suggesting that they are sediments derived from land.

Besides the dominantly terrigenous detritus in Site 209, trace amounts of glass shards, especially relatively clear unaltered glass found at various horizons throughout the section, suggest that minor amounts of air-fall volcanic ash periodically reached the site. The glasses have refractive index ranging from 1.52 to 1.58 , which indicate an intermediate composition. The glass ranges in color from colorless to shades of green and brown. The colored varieties of glass, as those in the other sites, have generally somewhat higher indexes of refraction.

\section{CORRELATION AND REGIONAL VOLCANISM}

\section{Abundance of Volcanic Constituents-Their Size and Correlation}

In Holes 204, 203, and 205, which are closest to the active volcanic centers of the Tonga-Kermadec Ridge system, volcanic materials form greater than 25 percent of much of the cores (Figure 1). These are also the only sites in which lapilli and a few larger-sized volcanic fragments were found and have a record of apparently continuous accumulation of volcanic detritus from at least the Oligocene through the present. Farther west, Sites 206, 208, and 210 show little sign of ash (Figure 7). Site 207, closest to volcanic centers of New Zealand, has a somewhat more complete record of ash accumulations, and Site 209, nearest to Australia, also has altered glass and crystals of plagioclase that probably had a pyroclastic origin.

For Site 203 the most likely source of the acid to acid intermediate volcaniclastic material is the line of volcanoes on the western margin of the Tonga Ridge, $150 \mathrm{~km}$ to the east (Figure 4). If the Lau Basin originated about 10 m.y. ago, as suggested in the site description, then the site of these volcanoes would have been located much closer, perhaps only $60 \mathrm{~km}$ away from the base of the drilled section at Site 230. Although no hypersthene has been found in the sediments, the presence of acid intermediate glass and very calcic feldspar like that of western Tonga Ridge volcanoes (Bryan et al., 1972) point to these volcanoes as a source of sediment and suggest that they were above sea level from at least the beginning of the Pliocene. The rounded and somewhat altered basalt fragments at the base of the sequence at Site 230 may represent volcanism association with the formation of new crust in the Lau Basin, which is thought to be tholeiitic basalt (Sclater et al., 1972). The volcanic material of basaltic composition in the upper part, on the other hand, may be related to Pleistocene volcanism on the Lau Ridge (Ladd and Hoffmeister, 1945) (Figure 4).

The variability in composition of volcanic detritus at Site 204 resembles that in volcanic rocks of the nearby Tonga-Kermadec arc system that continues into New Zealand; this arc system has had a long history of volcanism. The similarity between these volcanic rocks suggests that the arc system may be a general source for the detritus, but more work is required to locate the point of origin more precisely. The Louisville Ridge is another possible source for the volcanic detritus at Site 204, especially for Units 2 and 3 (Cretaceous) when the ridge may have been a major boundary between segments of the crust in the southwest Pacific, and thus may have been the locus of volcanism. However, pre-Late Eocene basalt occurs on Eua Island in the Tonga group, and it is possible that in its earliest stage of development, the Tonga Ridge was a source for Units 2 and 3.

The lithologic sequences of Cenozoic abyssal clay and ash overlying Cretaceous volcanigenic beds penetrated at Sites 52, 59, 60, and 61 (DSDP Legs 6 and 7) show a general resemblance to that of Site 204. However, in detail, the volcanic glasses in both the Cretaceous and Cenozoic parts of these more northerly, though tectonically similar, sites have refractive indexes generally less than 1.52 , which indicates an acidic $\left(>66\right.$ percent $\left.\mathrm{SiO}_{2}\right)$ composition.

The preponderance of volcaniclastic material throughout the section at Site 205, together with the presence of scattered lapilli-size pumice, indicates a proximity to volcanic centers situated on the Tonga and Lau Ridges. There is a decline in sedimentation rate at the top of the section at Site 105 that may be related to (1) a subsidence of the Lau Ridge that reduced the source of volcanic ash or (2) a deepening of the Lau Basin that could have trapped volcanic detritus coming from the Tonga Ridge.

The holes drilled west of the South Fiji Basin have much less volcanic constituents than those nearer the active volcanoes. Except for the rhyolite at the base of Hole 207, sediments with more than 10 percent volcanic constituents 
HOLE 209

WATER DEPTH $1438 \mathrm{~m}$

210

$4653 \mathrm{~m}$

208

$1555 \mathrm{~m}$

嵳 $L \underbrace{24 m \cdot y .)}_{30.0}$

岁 $M$

르 35.0

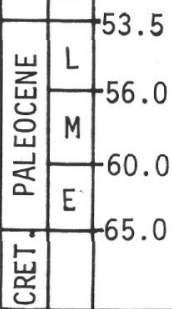
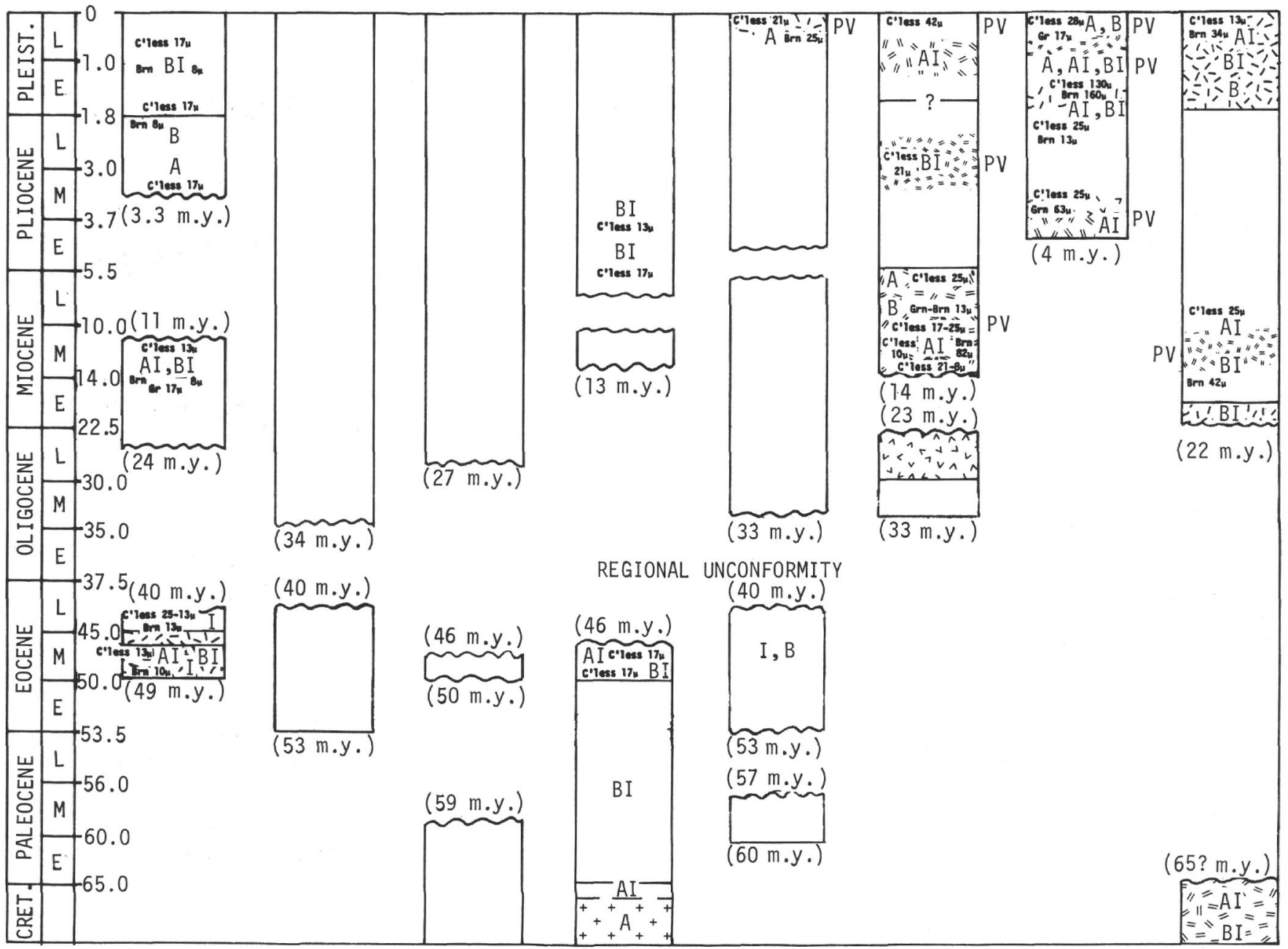

207

$1399 \mathrm{~m}$
206

$3206 \mathrm{~m}$
205

$4330 \mathrm{~m}$
203

$2730 \mathrm{~m}$
204

$5364 \mathrm{~m}$

Figure 7. Time correlation diagram showing the position of ash-rich horizons and their composition. (See Figures 1 and 2 for explanation of lithology symbols and letters.)

occur only in the Pleistocene at the top of Hole 206 and in the Middle Eocene in the lower part of Hole 209.

However, trace amounts of scattered volcanic detritus, mainly silt size grains of glass, feldspar (mainly plagioclase), and pyroxene (Augite where identified by X-ray) occur in much of the Cenozoic nanno ooze regardless of proximity to volcanic centers. In Holes 206, 208, and 210 the amount of volcanic detritus is especially low. For example, of 30 samples treated with acid to concentrate siliceous particles, only one yielded ash. Tertiary volcanic activity within the western region that may have been the source of the volcanic detritus includes New Zealand, Norfold Island, Lord Howe Island, and eastern Australia (Figures 4 and 5). With the data on hand, it is difficult to select a single source for a particular horizon in the western cores. The colored varieties of glass in Cores from Site 209, in the Quarternary part of the Section, could have come from Quaternary basalts in Queensland (Figure 4), but those lower in the Section may have come from basic and acid volcanoes in the Brisbane region of Australia (Figure 5). Some of the blass is plainly devitrified and may have provided silica to form replacement chert in the section. Older (Devonian to Early Cretaceous) volcanic rocks occur on the eastern margin of Queensland, and perhaps some of the more highly altered volcanic fragments were derived from them. Still another possible source for the glass in the lower part of the hole may be buried beneath the Queensland Plateau. If a northern source for the ash is postulated, such as the New Guinea-Solomon Islands, region, it is hard to explain the nearly ash-free section drilled at Site 210 intermediate in position between New Guinea and Site 207, although much ash may be masked by the turbidites. K-feldspar and intermediate glass shards in Units 2-3 at Site 209 represent probably several provenances-a terrestrial Australian provenance and an unidentified volcanic provenance perhaps related to opening of the Tasman Sea. The presence of substantial amounts of barite in the lower part of Site 208 , as in other deep-sea cores taken elsewhere, may be of far-reaching significance because barite has been shown to be related to high heat flow and submarine volcanism on 
the east Pacific Rise (Bostrom and Peterson, 1969) and more recently along other mid-ocean ridges. The barite in Site 208 may be related to the opening of the Tasman Sea and the creation of its crust. The rhyolite in the bottom of Hole 207, which is 92 m.y. old (van der Lingen, this volume), may also be related to the tectonic events that preceded the opening of the Tasman Sea about 80 m.y. ago. An increase in heat flow and crustal fusion that provided an acid magma may have occurred as an aftermath of the Rangitata Orogeny of New Zealand (Grindley et al., 1961). Extrusion of the rhyolite was followed by rifting and the formation of the oceanic crust of the Tasman sea. On the other side of the rift on the Australian coastline, there are no rhyolites of this age. However, there is a monzonite complex on the south coast of New South Wales, dated by Evernden and Richards (1962) at 94 m.y., that may be related to the same tectonic activity as the rhyolite.

Much of the siliceous detritus in these western sites, however, in the absence of associated ash beds, may be regarded as terrigenous. For example, the occasional quartz, feldspar, and pyroxene(?) grains in Site 206 may be airborne dust derived from New Zealand or Australia or perhaps detritus reflecting uplift on the Norfold Ridge. The silt and sand-size quartz and feldspar in Site 209 most likely came from nearby parts of Australia and are not products of airOfall ash as in the case of detritus in cores drilled in the eastern part of the region. On the other hand, Site 208 shows no evidence of substantial siliceous detritus being derived either from Australia or from New Caledonia. At Site 210, like Site 209, there is evidence of a terrestrial source in Units 3, 4, and 5. Unit 1, however, is primarily a turbidite sequence rich in terrigenous detritus including K-feldspar that probably came from New Guinea.

The sizes of volcanic fragments were studied in order to help determine their sources. The only sites at which lapilli and larger-sized fragments were found are Sites 203, 204, and 205 , closest to the active volcanic centers of the Tonga-Kermadec Ridge system (Figure 1). The sizes of glass shards studied on smear slides are shown in Figure 1 and weighted averages are summarized in Figure 7 . There is a wide range in size of glass shards. The smallest shards measured were $4 \mu$ and the largest, with few exceptions, measured under $200 \mu$. Again, the largest shards are concentrated in Sites 203, 204, and 205, nearest the Tonga-Kermadec Ridge system, their probable source at least for the Quaternary ashes. In Sites 207 and 209, the only western sites with substantial quantities of ash, the glass shards are smaller than those to the east. This suggests the glass in the western area may have had the same easterly or northeasterly source as in the eastern sites and was transported parallel to the present-day prevailing wind and current direction. However, the absence of shards in Site 208 intermediate between Sites 207 and 209 and the higher percentage of glass in Site 209 than in 207 suggests nearby Australian sources contributed glass to Site 209. There appears to be no obvious correlation of size of shards to their color, which reflects to some degree their composition. In Site 204 the colored shards are larger than the colorless shards. In Sites 203 and 206 no marked difference was noted, and in Sites 205 and 209 the colorless shards on the average appear to be larger.

\section{Composition of The Volcanic Material}

A systematic examination of volcanic glass shards was made to determine their refractive indexes (Figure 1). These data were then used to estimate their silica content and classify the shards as to lava type (Figure 2), taking into account associated crystals of feldspar and pyroxene. Most of the glass shards found in the various cores are colorless and relatively free of crystals and spherules and have indexes of refraction ranging from 1.52 to 1.57 . This indicates a range in $\mathrm{SiO}_{2}$ from about 66 to 52 percent and implies an intermediate or andesitic composition. Broken crystals of plagioclase (ranging from andesine to bytownite) and augite are the most common pyrogenic minerals associated with the glass shards. The highly calcic composition of plagioclase in Site 206 parallels those found in late Cenozoic lavas of western Tonga Ridge (Bryan et al., 1972). K-feldspar of probable volcanic origin occurs in the lower part of Unit 1, Site 204, but K-feldspar in Sites 208, 209 , and especially 210 probably had a terrigenous origin as did associated kaolin clay, metamorphic quartz, amphibole, and andesine.

More rarely, colorless glasses with refractive indexes less than 1.52 and colored glasses with indexes greater than 1.57 indicate that some acidic and basic glass, respectively, is present at each site. The occassional colorless glass shards with low indexes of refraction may have come from very distant volcanic centers because acidic volcanism is known to be more explosive and to produce much airborne pumice that can be carried long distances. Thus the colorless glass of acidic composition ( $n=1.51-1.504)$ found at the top of the section at Sites 203 and 206 conceivably could have been carried northward by wind from Taupo, New Zealand, a region of explosive rhyolitic eruptions during the Quaternary (Ninkovich, 1968) (Figure 3). However, a study of rhyolite ashes in deep-sea cores east of New Zealand suggests that a significant ash fall phases associated with eruption of New Zealand ignimbrites were carried as much as $1,000 \mathrm{~km}$ east of New Zealand (Ninkovich, 1968). Furthermore, glass in the ashes in deep-sea sediments east of New Zealand has refractive indexes, $n=1.498-1.500$, considerably less than those of most of the glasses indentified in this study. Some glass from Taupo, however, has an index as high as 1.507, which overlaps those of glass found here (Ewart, 1965). This apparent difference in composition of glass plus the prevailing northeasterly wind and water currents in the marginal ocean basins drilled behind the New Zealand-Kermadec-Tonga trend of active volcanoes suggeests an unidentified northeast source.

Much of the glass is devitrified, especially in lower parts of the cores, producing a wide range in the color of glass and in its refractive index. The presence of variable amounts of montmorillorite clay, zeolites (mainly identified in X-ray analyses as phillipsite and clinoptilolite), and tridymite-cristobalite indicates a variety of alteration products developed from the volcanic detritus.

$\mathrm{X}$-ray data indicate that in the Pliocene and Pleistocene section, mica (identified as biotite in Site 204) occurs in Sites 204 and 205 but not at Site 203. This may be due to differences in provenance or transport direction but also could be due to the unequal sampling. 


\section{Morphology of Clastic Volcanic Material}

The morphology of the clastic volcanic materials was briefly studied. Most of the lithic fragments of lapilli size were equant, angular to subrounded fragments. The glass shards, however, have several characteristic shapes seen in smear slides or with the use of a scanning electron microscope (Plate 1). The most easily distinguishalbe type is made of colorless pumice fragments characterized by pipe vesicles (Plate 1, Figures 1,2). The parallel arrangement of tubular vesicles separated by very thin vesicles walls controls the elongate shape of the fragments. In a few samples the pumice vesicles are nearly spherical (Plate 1, Figure 3), but some are pod shaped (Plate 1, Figures 5, 6).

The other major type of vitric ash is made of less vesicular glass. Many individual shards are flat, irregularly shaped fragments with pointed or conchoidal surfaces that are probably broken vesicle walls (Plate 1, Figures 4, 7-10, 12). Y-shaped shards found in places indicate that the grain shapes are largely dependent on vesicle density and shape. In general, the shapes of ashes described above are like those produced in andesitic or rhyolitic and dacitic magmatic eruptions from rapid release of gasses or frothing of high-viscosity magma as it reaches the surface (Heiken, 1972). On the other hand, a number of equant or pyramidal-shaped shards that have generally flat surfaces rather than curved surfaces or bubblelike inclusions may represent hyaloclastic ash formed by submarine eruptions. Most of these blocky shards studied here seem to be intermediate in composition and are closely associated with vesicular and curved shards; they may be products of phreatomagmatic eruptions that developed from time to time when rising magma at shallow depths came in contact with ground or surface water. Hyaloclastic ashes from deep sea eruptions are reported to be mainly basaltic ashes unlike those above (Bonatti, 1970).

\section{ACKNOWLEDGMENTS}

James G. Moore helped compare the basalt at the bottom of Site 205 with deep-sea basalt near Hawaii; Philip A. Frame did many of the refractive indices measurements and all of the size determinations of the glass; C. Nockolds helped provide SEM photographs of ashes; and Orrin Russia photographed cores from Sites 204 and 205.

\section{REFERENCES}

Bonatti, E., 1970. Deep sea volcanism: Naturwissenschaften, v. 57 , p. 379-384.
Bostrom, K. and Peterson, M. N. A., 1969. The origin of aluminum-poor ferromanganoan sediments in areas of high heat flow on the east Pacific rise. Marine Geol., v. 7, p. 427-447.

Bryan, W. B., Stice, G. D., and Ewart, A., 1972. Geology, petrography, and geochemistry of the volcanic islands of Tonga: J. Geophys. Res., v. 77, p. 1566-1585.

Commission for the Geological map of the World, 1965, 1967, 1971, Geological map of the world; Australia and Oceania, Sheets 7, 8, 9, 13, scale 1:5,000,000.

Evernden, J. F. and Richards, J. R., 1962. Potassium-argon ages in eastern Australia: J. Geol. Soc. Australia, v. 9, p. $1-50$.

Ewart, A., 1965. Mineralogy and petrogenesis of the Whakamaru ignimbrite in the Maraetai areas of the Taupo volcanic zone, New Zealand: New Zealand J. Geol. Geophys., v. 8, p. 611 .

Fisher, N. H., 1957. Catalogue of the active volcanoes and solfatara fields of Melanesia, Pt. 5. In Catalogue of the active volcanoes of the world: Internat. Volcano Assoc., v. 105 .

George, W., 1924. The relations of the physical properties of natural glass to chemical composition: J. Geol., v. 32, p. 353-372.

Grindley, G. W., Harrington, H. J., and Wood, B. L., 1961. The geological map of New Zealand, 1:2,000,000: New Zealand Geol. Surv. Bull., v. 66.

Heiken, G., 1972. Morphology and petrography of volcanic ashes: Geol. Soc. Am. Bull., v. 83, p. 1961-1988.

Ladd, H. S. and Hoffmeister, J. E., 1945. Geology of Lau, Fiji: Bernice P. Bishop Mus. Bull., v. 181, p. 399.

Moore, J. G., 1965. Petrology of deep-sea basalt near Hawaii: Am. J. Sci., v. 263, p. 40-52.

Moore, J. G. and Calk, L., 1971. Sulphide spherules in vesicles of dredged pillow basalt: Am. Mineral., v. 56, p. 476-488.

Ninkovich, D., 1968. Pleistocene volcanic eruptions in New Zealand recorded in deep-sea sediments: Earth Planet. Sci. Letters, v. 4, p. 89-102.

Richard, J. J., 1962. Catalogue of the active volcanoes and solfatara fields of Kermadec, Tonga and Samoa, Pt. 13. In Catalogue of the active volcanoes of the world: Internat. Volcano Assoc., v. 38.

Sclater, J. G., Hawkins, J. W., Mammerickx, J., and Chase, C. G., 1972, Crustal extension between the Tonga and Lau Ridges; petrologic and geophysical evidence: Geol. Soc. Am. Bull., v. 83, p. 505-518.

Williams, H., Turner, F. J., Gilbert, C. M., 1955. Petrography-an introduction to the study of rocks and thin sections: San Francisco (Freeman and Co.). 
PLATE 1

Figures 1-4 Pleistocene ash 116 meters below sea floor, Site 203-3-5, 85-86 cm.

1. Glass shards and pumice fragments of intermediate composition. Equant shards have relatively low vesicularity, spherical vesicles, and smooth fracture surfaces. Magnification 60X.

2. Close-up of colorless pumice fragment with pipe vesicles from Figure 1, lower left corner. Magnification 300X.

3. Highly vesicular glass shard with generally spherical vesicles. Magnification 600X.

4. Close-up of glass shard with very low vesicularity and some conchoidal fracture surfaces. Magnification $60 \times$.

Figures 5, 6 Middle Miocene ash 150 meters below sea floor, Site 205-23-5, 71-77 cm.

5. Mostly devitrified pumice with lens-shaped vesicles. Magnification 300X.

6. Close-up of Figure 5. Magnification 10,000X.

Figure 7 Glass shards of intermediate composition $n=1.580-1.534$ mostly 1.526-1.530. Most curved surfaces are broken vesicle walls. Some are conchoidal fractures. Pliocene ash 400 meters below sea floor, Site 203-5-1, 77-78 cm. Magnification 600X.

Figures 8-10, 12 Glass shards of acidic to intermediate composition that are characterized by flat to crudely triangular shapes. Overall shape and curvature of surfaces influenced largely by vesicle shape and distribution.

8. Middle Miocene ash about 135 meters below sea floor, Site 205-15-3, 130- $132 \mathrm{~cm}$, magnification 400X.

9. Pleistocene acidic ash about 7 meters below sea floor, Site 206-2-2, $72-73 \mathrm{~cm}$, magnification 300X.

10. Quaternary ash 4.5 meters below sea floor, Site 204-1-3, 5-6 cm, magnification 100X.

12. Close-up of individual glass shard showing conchoidal fracture surfaces. Middle Miocene, 51 meters below sea floor, Site 204-3-2, 58-60 cm., magnification $300 \mathrm{X}$.

Figure 11 Basalt glass and broken crystals of fresh olivine crystals. Glass has a refractive index of 1.580 and is characterized by low vesicularity and conchoidal fracture surfaces. Dominance of fracture surfaces suggests that they were produced by drilling of basalt flow or intrusive rock. Pliocene or younger, about 400 meters below sea floor, Site 203-5-1, 13-15 cm. Magnification 60X. 

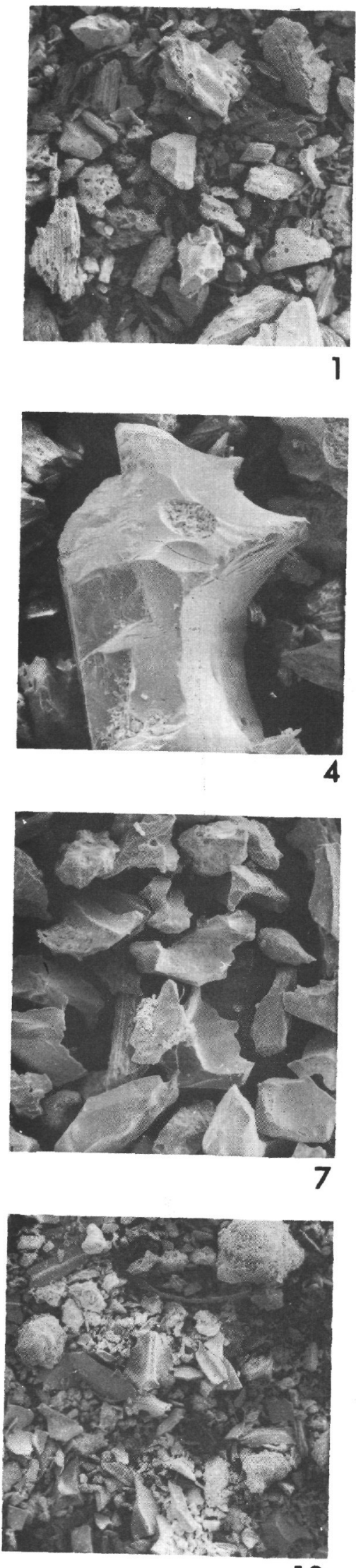

10
PLATE 1

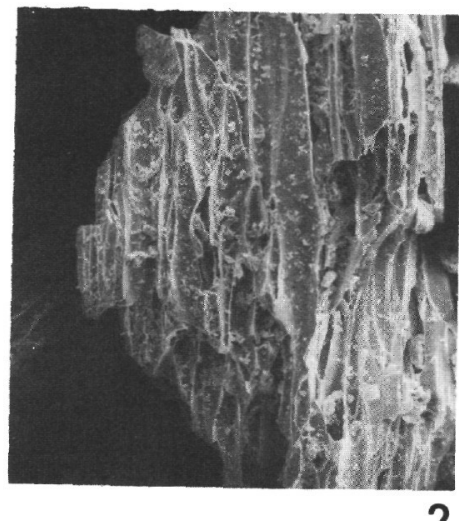

2
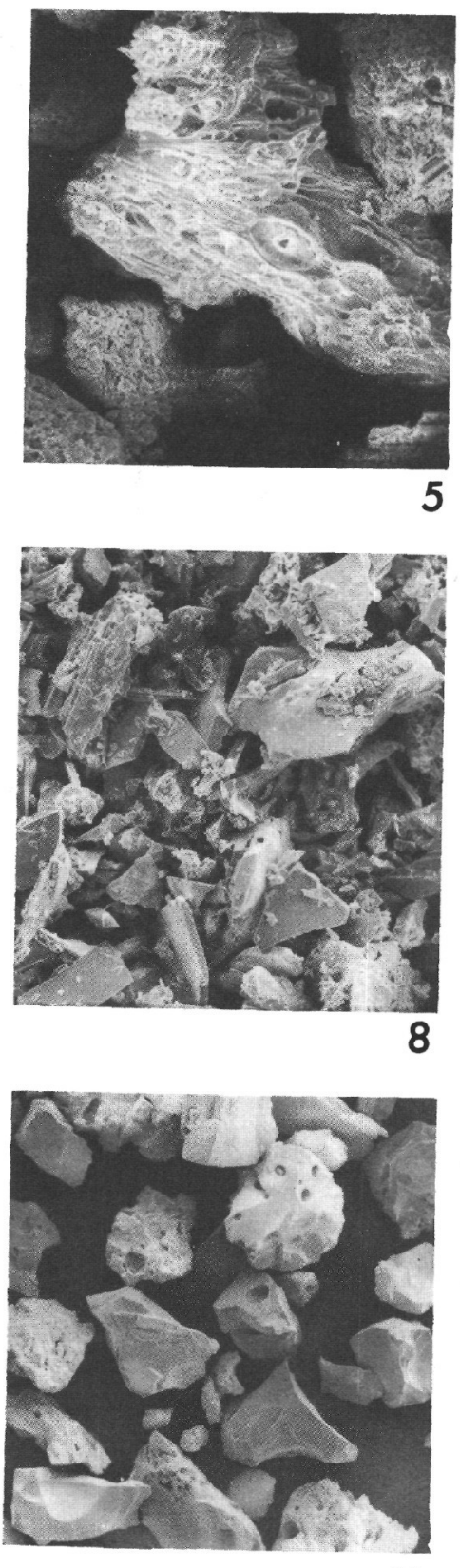
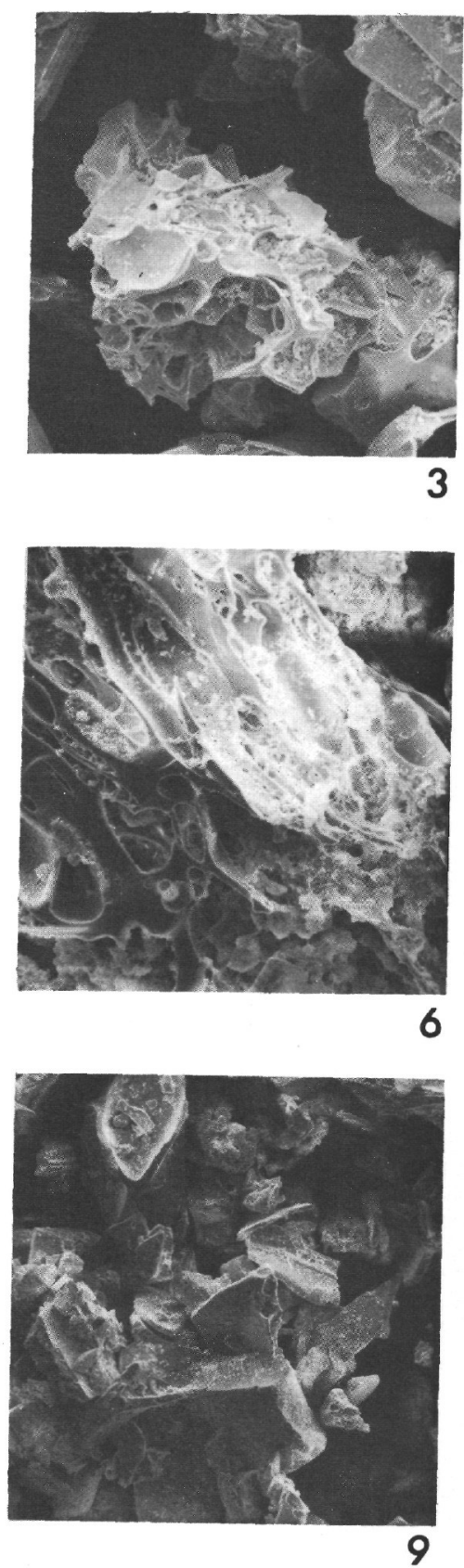

6

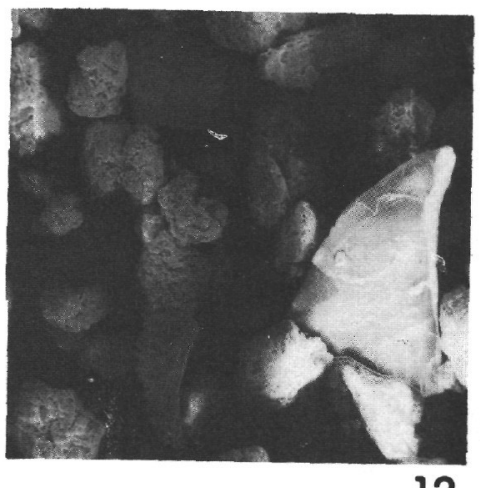

12 